\title{
OPEN Seagrass blue carbon stocks and sequestration rates in the Colombian Caribbean
}

\author{
Oscar Serrano ${ }^{1,2 凹}$, Diana Isabel Gómez-López ${ }^{3}$, Laura Sánchez-Valencia ${ }^{3}$, \\ Andres Acosta-Chaparro ${ }^{3}$, Raul Navas-Camacho ${ }^{3}$, Juan González-Corredor ${ }^{3}$, Cristian Salinas ${ }^{1}$, \\ Pere Masque ${ }^{1,4}$, Cesar A. Bernal ${ }^{3} \&$ Núria Marbà $^{5}$
}

Seagrass ecosystems rank amongst the most efficient natural carbon sinks on earth, sequestering $\mathrm{CO}_{2}$ through photosynthesis and storing organic carbon $\left(\mathrm{C}_{\text {org }}\right)$ underneath their soils for millennia and thereby, mitigating climate change. However, estimates of $\mathrm{C}_{\text {org }}$ stocks and accumulation rates in seagrass meadows (blue carbon) are restricted to few regions, and further information on spatial variability is required to derive robust global estimates. Here we studied soil $\mathrm{C}_{\text {org }}$ stocks and accumulation rates in seagrass meadows across the Colombian Caribbean. We estimated that Thalassia testudinum meadows store $241 \pm 118 \mathrm{Mg} \mathrm{C}_{\text {org }}$ ha $^{-1}$ (mean \pm SD) in the top $1 \mathrm{~m}$-thick soils, accumulated at rates of $122 \pm 62$ and $15 \pm 7 \mathrm{~g} \mathrm{C}_{\text {org }} \mathrm{m}^{-2}$ year ${ }^{-1}$ over the last $\sim 70$ years and up to 2000 years, respectively. The tropical climate of the Caribbean Sea and associated sediment runoff, together with the relatively high primary production of $T$. testudinum, influencing biotic and abiotic drivers of $C_{\text {org }}$ storage linked to seagrass and soil respiration rates, explains their relatively high $\mathrm{C}_{\text {org }}$ stocks and accumulation rates when compared to other meadows globally. Differences in soil $C_{\text {org }}$ storage among Colombian Caribbean regions are largely linked to differences in the relative contribution of $C_{\text {org }}$ sources to the soil $C_{\text {org }}$ pool (seagrass, algae Halimeda tuna, mangrove and seston) and the content of soil particles $<0.016 \mathrm{~mm}$ binding $C_{\text {org }}$ and enhancing its preservation. Despite the moderate areal extent of $T$. testudinum in the Colombian Caribbean $\left(661 \mathrm{~km}^{2}\right)$, it sequesters around $0.3 \mathrm{TgCO}_{2}$ year $^{-1}$, which is equivalent to $\sim 0.4 \%$ of $\mathrm{CO}_{2}$ emissions from fossil fuels in Colombia. This study adds data from a new region to a growing dataset on seagrass blue carbon and further explores differences in meadow $C_{\text {org }}$ storage based on biotic and abiotic environmental factors, while providing the basis for the implementation of seagrass blue carbon strategies in Colombia.

Seagrass meadows rank amongst the most prized ecosystems on Earth due to the provision of vital ecosystem services such as nutrient cycling, biodiversity and contribution to climate change mitigation and adaption through carbon sequestration and coastal protection despite they occupy less than $0.1 \%$ of the global marine surface $^{1,2}$. Facing the urgency to reduce atmospheric greenhouse gases to mitigate climate change, the strategy known as blue carbon builds up on the conservation and restoration of coastal vegetated ecosystems (mangrove forests, tidal marshes, seagrass meadows and macroalgae beds) to enhance and preserve their capacity to act as natural carbon sinks ${ }^{3}$. It is estimated that seagrass globally store $140 \mathrm{Mg}$ organic carbon $\left(\mathrm{C}_{\text {org }}\right)$ per hectare in the top meter of soils, accumulated over centennial-millenial time scales, being up to 40 times more efficient at capturing organic carbon $\left(\mathrm{C}_{\text {org }}\right)$ than land forests soils ${ }^{4,5}$.

Despite those benefits and services provided, seagrasses are among the most threatened ecosystems on the planet, and widespread die-off of seagrasses has been estimated at $0.9 \%$ year $^{-1}$, due to a diversity of pressures including coastal development and coupled nutrient and sediment discharges causing eutrophication and siltation, respectively ${ }^{6}$. More recently, local conservation and management actions resulted in the deceleration and reversal of seagrass declining trends in Europe ${ }^{7}$ and $\mathrm{USA}^{8}$. However, it has been estimated that $0.15 \mathrm{Pg}$ of $\mathrm{CO}_{2}$ may be released annually from disturbed seagrass ecosystems, which is equivalent to $3 \%$ of those from

\footnotetext{
${ }^{1}$ School of Science and Centre for Marine Ecosystems Research, Edith Cowan University, Joondalup, WA, Australia. ${ }^{2}$ Centro de Estudios Avanzados de Blanes, Consejo Superior de Investigaciones Científicas, Blanes, Spain. ${ }^{3}$ Marine and Coastal Research Institute "José Benito Vives De Andréis" INVEMAR, Calle 25 No. 2-55, Santa Marta, Colombia. ${ }^{4}$ International Atomic Energy Agency, 98000 Principality of Monaco, Monaco. ${ }^{5}$ Global Change Research Group, IMEDEA (CSIC-UIB), Institut Mediterrani D’Estudis Avançats, Miquel Marquès 21, 07190 Esporles, Spain. ${ }^{\boxplus}$ email: o.serranogras@ecu.edu.au
} 
deforestation globally 9 . The inclusion of seagrass conservation and restoration projects into carbon crediting markets could provide a financial incentive to preserve the ecosystem services they provide, including their role in $\mathrm{C}_{\text {org }}$ storage and climate change mitigation and adaptation ${ }^{10}$.

Seagrass meadows are found along the shores of all continents except Antarctica occupying a global area estimated to range between 0.27 to 1.65 million ${ }^{2,11,12} \mathrm{~km}^{2}$, and encompass about 70 seagrass species ${ }^{13}$. Seagrass species have a broad dissimilarity in traits including differences in biomass and primary production rates ${ }^{14}$, that also vary across environmental conditions such as water depth and geomorphology ${ }^{15,16}$. Such differences in biotic and abiotic habitat characteristics result in up to 18 -fold variability in $\mathrm{C}_{\text {org }}$ storage capacity across seagrass ecosystems ${ }^{17}$. An increasing number of studies are reporting seagrass blue carbon stocks and accumulation rates at local, regional and global scales ${ }^{5,18-23}$. However, there is a scarcity of seagrass blue carbon estimates in American countries, with the exception of Mexico, Canada, the United States in North America, and a few studies in Central and South America (Brazil, Panama and Dutch Caribbean) $)^{5,20,23-29}$. The scarcity of seagrass blue carbon studies in these key regions is limiting our capacity to derive robust global estimates while precluding their incorporation into national carbon accounting and the implementation of blue carbon strategies within Nationally Declared Contributions to mitigate climate change.

The Caribbean Sea, a tropical region with climates ranging from semi-arid to rain forests, provides a case for a region which is currently not represented in global estimates of seagrass blue carbon. Seagrasses grow in reef lagoons between the beaches and coral reefs in the Caribbean, and can form extensive meadows in protected embayment's and estuaries. Out of the seven seagrass species found within the Caribbean Sea, Thalassia testudinum (turtle grass) is the most abundant species and forms persistent and climax seagrass ecosystems in the region ${ }^{13}$. The current area of T. testudinum seagrass beds in the Colombian Caribbean has been estimated in $661 \mathrm{~km}^{2}$, but extensive losses have also been documented ${ }^{30}$. For instance, Cartagena Bay experienced more than $90 \%$ reduction in seagrass extent over the past decades (from 2.5 to $0.18 \mathrm{~km}^{2}$ ) attributed to local anthropogenic disturbances ${ }^{31}$. Past and current anthropogenic threats to seagrass in the Caribbean region include coastal development, mining, sediment run-off and pollution, while natural threats are mainly related to hurricanes ${ }^{32}$.

This study aims to provide estimates of seagrass soil $\mathrm{C}_{\text {org }}$ stocks and accumulation rates for the underrepresented Colombian Caribbean (Fig. 1), based on biotic and abiotic environmental factors interacting at regional scales. We combine estimates of $\mathrm{C}_{\text {org }}$ density in $1 \mathrm{~m}$-thick soils from $T$. testudinum meadows with soil accumulation rates derived from sediment chronologies determined with ${ }^{210} \mathrm{~Pb}$ and ${ }^{14} \mathrm{C}$ to estimate soil $\mathrm{C}_{\text {org }}$ stocks within the top meter of soil and short- (last 70 years) and long-term (last 2000 years) soil $\mathrm{C}_{\text {org }}$ accumulation rates. We also assess differences in soil $\mathrm{C}_{\text {org }}$ storage among habitats based on the contribution of seagrass- $\mathrm{C}_{\text {org }}$ and allochthonous- $\mathrm{C}_{\text {org }}$ sources to the soil $\mathrm{C}_{\text {org }}$ pool, and sediment grain-size. The information gathered provides baseline values for future development of blue carbon strategies in Colombia as well as key information for regional and national marine planning and governance based on seagrass blue carbon ecosystem service.

\section{Results}

Compression of seagrass soils during coring operations averaged $37 \pm 16 \%$ (mean \pm SD; Supplementary Information Table A). The top meter of seagrass soils of the Colombian Caribbean had a mean \pm SD dry bulk density (DBD) of $0.87 \pm 0.32 \mathrm{~g} \mathrm{~cm}^{-3}$, containing $6.6 \pm 4.0 \%$ organic matter $(\mathrm{OM}), 1.2 \pm 0.9 \%$ organic carbon $\left(\mathrm{C}_{\mathrm{org}}\right)$ and $7.9 \pm 3.5 \mathrm{mg} \mathrm{C}_{\text {org }} \mathrm{cm}^{-3}$ (Table 1). Seagrass soils were mainly constituted of particles $>0.016<0.125 \mathrm{~mm}(33 \pm 24 \%)$, with a relatively high abundance of particles $<0.016 \mathrm{~mm}(11 \pm 14 \%)$ and coarse sands $>0.5 \mathrm{~mm}(21 \pm 21 \%)$. Soil $\mathrm{C}_{\text {org }}$ stocks in the top first meter ranged from 39 to $673 \mathrm{Mg} \mathrm{C}_{\text {org }}$ ha $^{-1}\left(241 \pm 118 \mathrm{Mg} \mathrm{C}_{\text {org }}\right.$ ha $^{-1}$; Table 1).

A total of 11 cores were processed to determine the sedimentation rates during the last decades using the ${ }^{210} \mathrm{~Pb}$ dating method. Due to the high degree of mixing presented in five of the cores analyzed, it was only possible to determine sediment accumulation rates in six cores. It was possible to estimate sedimentation rates during the last 500-2000 years using the ${ }^{14} \mathrm{C}$ dating method in five cores, based on one to three radiocarbon results per core (Supplementary Information Table B). Short- and long-term soil accretion rates (SAR) ranged from 0.9 to $7.0 \mathrm{~mm}_{\text {year }}^{-1}\left(3.9 \pm 0.4 \mathrm{~mm}\right.$ year $\left.^{-1}\right)$ and 0.37 to $3.4 \mathrm{~mm} \mathrm{year}^{-1}\left(1.8 \pm 0.9 \mathrm{~mm}^{-1} \mathrm{ear}^{-1}\right)$, respectively, while shortand long-term $\mathrm{C}_{\text {org }}$ accumulation rates (CAR) ranged from 34 to $195 \mathrm{~g} \mathrm{C}_{\text {org }} \mathrm{m}^{-2}$ year $^{-1}\left(122 \pm 62 \mathrm{~g} \mathrm{C}_{\text {org }} \mathrm{m}^{-2}\right.$ year $^{-1}$ ) and from 2.2 to $27.5 \mathrm{~g} \mathrm{C}_{\text {org }} \mathrm{m}^{-2}$ year $^{-1}\left(14.9 \pm 7.2 \mathrm{~g} \mathrm{C}_{\text {org }} \mathrm{m}^{-2}\right.$ year $\left.{ }^{-1}\right)$, respectively (Table 2$)$.

The $\delta^{13} \mathrm{C}$ values of sedimentary organic $\mathrm{C}_{\text {org }}$ in seagrass soils averaged $-19.4 \pm 2.8 \%$. The $\delta^{13} \mathrm{C}$ values of seagrass, mangrove, seston and Halimeda tuna (Supplementary Information Table C) were used to run mixing models to estimate the contribution of potential sources into the sedimentary $\mathrm{C}_{\text {org }}$ pool. Seagrass detritus and seston were the most important source of $C_{\text {org }}$ in seagrass soils from the Colombian Caribbean $(39 \pm 13 \%$ and $36 \pm 24 \%$, respectively), with the exception of meadows at San Andrés where macroalgae $H$. tuna contributed $47 \pm 29 \%$. Mangrove matter contributed $27 \pm 15 \%$ across Alta Guajira, Tayrona and Cartagena Bay regions where mangroves are present (Fig. 2). Overall, $\mathrm{C}_{\mathrm{org}}\left(\%\right.$ and $\mathrm{mg} \mathrm{C}_{\mathrm{org}} \mathrm{cm}^{-3}$ ) contents increased with increasing fine particle contents $(\%<0.016 \mathrm{~mm})$ in all regions except Alta Guajira (Fig. 3). There was a lack of relationship between $\delta^{13} \mathrm{C}$ and $\mathrm{C}_{\text {org }}\left(\%\right.$ and $\left.\mathrm{mg} \mathrm{C}_{\text {org }} \mathrm{cm}^{-3}\right)$ contents.

The DBD increased with soil depth in the seagrass meadows at Alta Guajira, Media Guajira and San Andrés, but remained relatively stable at Tayrona and Cartagena Bay (Supplementary Information Figure A). OM and $\mathrm{C}_{\text {org }}$ contents decreased with soil depth at all sites, while $\delta^{13} \mathrm{C}$ remained stable with soil depth. The content of particles $<0.016 \mathrm{~mm}$ remained relatively stable along soil depth, with the exception of higher content below $100 \mathrm{~cm}$ depth at Cartagena Bay. Coarse sand $(>0.5 \mathrm{~mm})$ content was relatively higher within the upper 20 to $90 \mathrm{~cm}$ at Alta Guajira, Media Guajira and Cartagena Bay, while oscillated between 5 to $40 \%$ along the soil cores at San Andrés.

Soil biogeochemical characteristics $\left(\mathrm{DBD}, \% \mathrm{C}_{\text {org }}, \% \mathrm{OM}, \delta^{13} \mathrm{C}\right.$, and particles $<0.016 \mathrm{~mm},>0.016<0.125 \mathrm{~mm}$ and $>0.5 \mathrm{~mm})$ and soil $\mathrm{C}_{\text {org }}$ stocks were significantly different $(\mathrm{P}<0.05)$ among regions (Alta Guajira, Media Guajira, Tayrona, Cartagena Bay and San Andrés; Table 3). Soil DBD in meadows at Alta Guajira $\left(0.7 \pm 0.3 \mathrm{~g} \mathrm{~cm}^{-3}\right)$ 


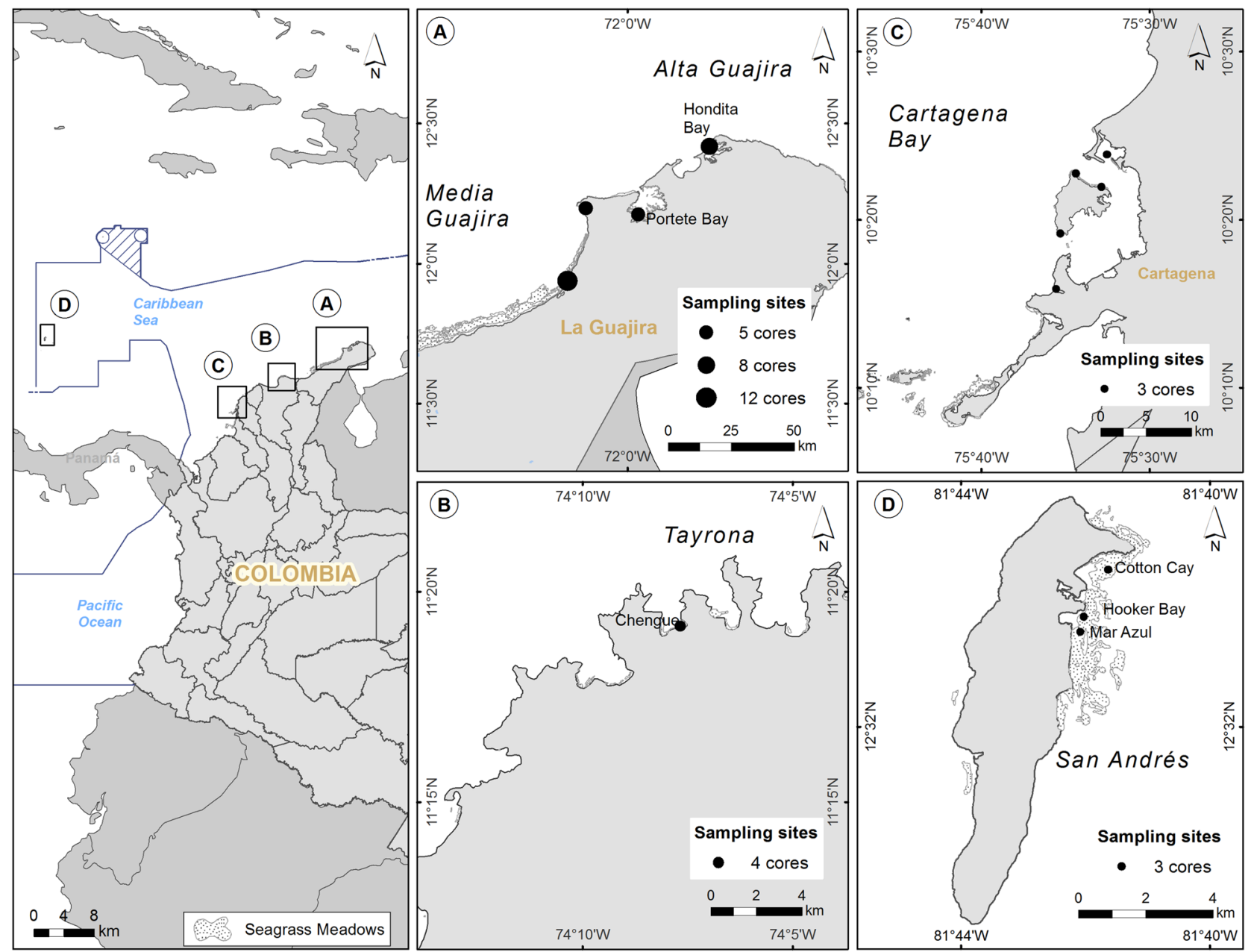

Figure 1. Seagrass meadow distribution and location of the sampling sites in the Colombian Caribbean. Left panel shows the location of the five regions studied (Alta Guajira, Media Guajira, Cartagena Bay, Tayrona and San Andrés). (A-D) show the sampling sites within each region. The size of the circles indicates the number of cores studied at each sampling site. The maps were created in ArcGis Online (https://www.esri.com/en-us/ arcgis/products/arcgis-online/overview).

and San Andrés $\left(0.7 \pm 0.2 \mathrm{~g} \mathrm{~cm}^{-3}\right)$ were significantly lower than at the other regions (average ranging from 1.0 to $1.1 \mathrm{~g} \mathrm{~cm}^{-3}$; Fig. 4). The soil OM content was significantly higher in Alta Guajira (9.7 $\left.\pm 4.6 \% \mathrm{OM}\right)$ compared to meadows at San Andrés (6.9 $\pm 2.5 \%$ OM), while OM content at both Alta Guajira and San Andrés was higher than at Media Guajira, Tayrona and Cartagena Bay (ranging from 3.9 to 5.3\%; Table 3). The soil $\mathrm{C}_{\text {org }}$ content followed a similar pattern, with significantly higher values at Alta Guajira $\left(1.54 \pm 1.02 \% \mathrm{C}_{\text {org }}\right)$ and San Andrés $\left(1.47 \pm 0.80 \% \mathrm{C}_{\text {org }}\right)$ compared to Media Guajira $\left(0.52 \pm 0.16 \% \mathrm{C}_{\text {org }}\right)$. The $\mathrm{C}_{\text {org }}$ stocks within the top meter of soil were up to twofold higher in Alta Guajira $\left(353 \pm 125 \mathrm{Mg} \mathrm{C}_{\text {org }}\right.$ ha $\left.^{-1}\right)$ compared to Cartagena Bay $\left(142 \pm 61 \mathrm{Mg} \mathrm{C}_{\text {org }}\right.$ $\mathrm{ha}^{-1}$ ), while the other regions had intermediate soil $\mathrm{C}_{\text {org }}$ stocks with average values ranging from 210 to $241 \mathrm{Mg}$ $\mathrm{C}_{\text {org }} \mathrm{ha}^{-1}$. The lower number of SAR and CAR data across regions precluded comparisons. The $\delta^{13} \mathrm{C}$ values of soil $C_{\text {org }}$ were significantly lower in Alta and Media Guajira (average ranging from -21 to $-22 \%$ ) than in San Andrés $(-16 \pm 1.4 \% 0)$. Based on isotope mixing models, seagrass was the major contributor to the soil $\mathrm{C}_{\text {org }}$ pool in the meadows located at Alta Guajira, Tayrona and Cartagena Bay (46\% in all cases), with 25\% contributions of each seston and mangrove matter (Fig. 2). At Media Guajira, seston contributed 69\%, while seagrass contributed the remaining $31 \%$. The contribution of $H$. tuna to soil $\mathrm{C}_{\text {org }}$ pool at San Andrés was estimated at $47 \%$, with seagrass and seston contributing $27 \%$ each. Seagrass soils at Alta Guajira had significantly higher amount of particles $<0.016 \mathrm{~mm}(30 \pm 15 \%)$ than the other regions (ranging from 2 to $13 \%$ ), while particles $>0.016<0125 \mathrm{~mm}$

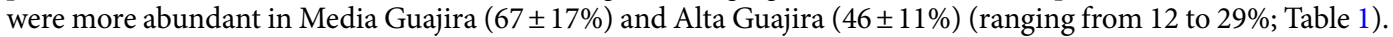
The concentration of coarse sands $>0.5 \mathrm{~mm}$ was significantly higher in Cartagena Bay $(40 \pm 15 \%)$ compared to the other regions (ranging from 4 to $19 \%$ ). 


\begin{tabular}{|c|c|c|c|c|c|c|c|c|c|c|c|c|c|c|c|c|c|}
\hline \multirow[b]{2}{*}{ Region } & \multirow[b]{2}{*}{ Location } & \multirow[b]{2}{*}{ Core ID } & \multicolumn{2}{|c|}{$\begin{array}{l}\text { DBD }(g \\
\left.\mathrm{cm}^{-3}\right)\end{array}$} & \multicolumn{2}{|c|}{$\mathrm{C}_{\text {org }}(\%)$} & \multicolumn{2}{|c|}{ ом (\%) } & \multicolumn{2}{|c|}{$\delta^{13} \mathrm{C}(\%)$} & \multicolumn{2}{|c|}{$\begin{array}{l}<0.016 \mathrm{~mm} \\
(\%)\end{array}$} & \multicolumn{2}{|c|}{$\begin{array}{l}>0.016<0.125 \mathrm{~mm} \\
(\%)\end{array}$} & \multicolumn{2}{|c|}{$>0.5 \mathrm{~mm}$} & \multirow{2}{*}{ 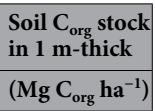 } \\
\hline & & & Mean & SD & Mean & SD & Mean & SD & Mean & SD & Mean & SD & Mean & SD & Mean & SD & \\
\hline Alta Guajira & Cabo de la Vela & AGCV1 & 1.0 & 0.2 & & & 5.0 & 0.8 & & & & & & & & & 224 \\
\hline & & AGCV2 & 1.0 & 0.0 & & & 4.9 & 0.7 & & & & & & & & & 246 \\
\hline & & AGCV3 & 0.9 & 0.0 & & & 4.2 & 0.6 & & & & & & & & & 203 \\
\hline & & AGCV4 & 1.1 & 0.1 & & & 4.5 & 1.8 & & & & & & & & & 279 \\
\hline & & AGCV5 & 0.9 & 0.0 & & & 6.2 & 0.9 & & & & & & & & & 329 \\
\hline & Portete Bay & AGBP1 & 0.6 & 0.2 & & & 16.8 & 5.2 & & & & & & & & & 673 \\
\hline & & AGBP2 & 0.4 & 0.2 & & & 14.8 & 4.7 & & & & & & & & & 344 \\
\hline & & AGBP3 & 0.7 & 0.1 & & & 10.7 & 5.0 & & & & & & & & & 470 \\
\hline & & AGBP4 & 0.6 & 0.1 & & & 10.3 & 2.8 & & & & & & & & & 369 \\
\hline & & AGBP5 & 0.7 & 0.1 & & & 5.7 & 0.1 & & & & & & & & & 235 \\
\hline & Hondita Bay & AGBH1 & 0.8 & 0.0 & & & 10.3 & 3.6 & & & & & & & & & 415 \\
\hline & & AGBH2 & 0.8 & 0.1 & & & 8.4 & 3.0 & & & & & & & & & 370 \\
\hline & & AGBH3 & 0.8 & 0.3 & 1.3 & 1.1 & 8.9 & 3.2 & -21.4 & 1.3 & 16.7 & 5.7 & 41.5 & 12.5 & 11.8 & 14.9 & 266 \\
\hline & & AGBH4 & 0.9 & 0.2 & & & 10.8 & 4.1 & & & & & & & & & 479 \\
\hline & & AGBH5 & 0.8 & 0.2 & & & 8.2 & 1.7 & & & & & & & & & 381 \\
\hline & & AGBH6 & 0.5 & \begin{tabular}{|l|}
0.1 \\
\end{tabular} & 1.8 & 0.9 & 11.6 & 3.4 & -20.3 & 2.0 & 45.6 & 2.0 & 52.0 & 1.9 & 0.0 & 0.0 & 206 \\
\hline & & AGBH7 & 0.5 & 0.0 & & & 12.1 & 2.6 & & & & & & & & & 350 \\
\hline & & AGBH8 & 0.6 & 0.1 & & & 15.9 & 3.5 & & & & & & & & & 522 \\
\hline Media Guajira & Carrizal & MGCZ1 & 1.2 & 0.1 & & & 3.3 & 2.0 & & & & & & & & & 151 \\
\hline & & MGCZ2 & 1.1 & \begin{tabular}{|l|}
0.1 \\
\end{tabular} & & & 6.5 & 1.8 & & & & & & & & & 357 \\
\hline & & MGCZ3 & 1.1 & 0.3 & & & 5.2 & 1.2 & & & & & & & & & 258 \\
\hline & & MGCZ4 & 1.1 & 0.2 & 0.5 & 0.1 & 2.4 & 0.7 & -21.5 & 0.6 & 4.8 & 0.1 & 64.9 & 1.9 & 1.2 & 2.3 & 108 \\
\hline & & MGCZ5 & 1.1 & \begin{tabular}{|l|l|}
0.1 \\
\end{tabular} & & & 2.9 & 0.6 & & & & & & & & & 153 \\
\hline & & MGCZ6 & 1.0 & \begin{tabular}{|l|l|}
0.1 \\
\end{tabular} & & & 3.5 & 1.2 & & & & & & & & & 159 \\
\hline & & MGCZ7 & 0.9 & 0.2 & & & 3.6 & 4.1 & & & & & & & & & 130 \\
\hline & & MGCZ8 & 1.0 & 0.2 & & & 5.7 & 3.9 & & & & & & & & & 203 \\
\hline & & MGCZ9 & 1.1 & \begin{tabular}{|l|}
0.1 \\
\end{tabular} & & & 5.3 & 0.9 & & & & & & & & & 252 \\
\hline & & MGCZ10 & 1.0 & 0.3 & 0.5 & 0.2 & 3.6 & 0.6 & -20.0 & 0.9 & 3.4 & 1.7 & 71.0 & 18.3 & 2.3 & 6.4 & 145 \\
\hline & & MGCZ11 & 1.0 & 0.0 & & & 5.6 & 2.5 & & & & & & & & & 309 \\
\hline & & MGCZ12 & 1.1 & \begin{tabular}{|l|}
0.1 \\
\end{tabular} & & & 4.7 & 3.6 & & & & & & & & & 267 \\
\hline & Musichi & MGMC1 & 1.2 & 0.3 & 0.6 & 0.1 & 3.2 & 1.9 & -22.8 & 1.0 & 3.5 & 0.8 & 64.4 & 21.1 & 6.8 & 10.0 & 139 \\
\hline & & MGMC2 & 1.3 & \begin{tabular}{|l|}
0.1 \\
\end{tabular} & & & 2.9 & 0.9 & & & & & & & & & 176 \\
\hline & & MGMC3 & 1.1 & 0.3 & & & 5.2 & 2.6 & & & & & & & & & 338 \\
\hline San Andrés & Mar Azul & SAMA1 & 0.6 & 0.1 & 1.5 & 0.5 & 7.6 & 2.8 & -16.5 & 1.0 & 23.5 & 3.0 & 35.9 & 4.1 & 0.0 & 0.0 & 193 \\
\hline & & SAMA2 & 0.7 & \begin{tabular}{|l|}
0.1 \\
\end{tabular} & & & 7.5 & 0.9 & & & & & & & & & 251 \\
\hline & & SAMA3 & 0.7 & 0.1 & & & 5.9 & 0.8 & & & & & & & & & 209 \\
\hline & Hooker Bay & SABH1 & 0.6 & 0.2 & 1.7 & 0.9 & 8.2 & 1.7 & -15.3 & 1.4 & \begin{tabular}{|l|l|}
10.8 \\
\end{tabular} & 3.6 & 33.4 & 6.7 & 17.6 & 11.3 & 206 \\
\hline & & SABH2 & 0.8 & 0.2 & & & 7.4 & 3.2 & & & & & & & & & 258 \\
\hline & & SABH3 & 0.8 & 0.2 & & & 5.6 & 4.0 & & & & & & & & & 179 \\
\hline & Cotton Cay & SACC1 & 0.9 & 0.2 & 1.1 & 0.8 & 4.9 & 1.6 & -17.2 & 1.1 & 5.7 & 5.9 & 15.6 & 11.9 & 41.9 & 19.4 & 197 \\
\hline & & SACC2 & 1.0 & 0.1 & & & 6.5 & 1.2 & & & & & & & & & 331 \\
\hline & & SACC3 & 1.1 & 0.1 & & & 5.9 & 1.1 & & & & & & & & & 343 \\
\hline Tayrona & Chengue Bay & SMCH1 & 0.7 & \begin{tabular}{|l|}
0.1 \\
\end{tabular} & & & 6.4 & 3.1 & & & & & & & & & 217 \\
\hline & & SMCH2 & 1.0 & 0.1 & & & 5.0 & 1.4 & & & & & & & & & 229 \\
\hline & & SMCH3 & 1.2 & \begin{tabular}{|l|}
0.1 \\
\end{tabular} & & & 5.2 & 1.5 & & & & & & & & & 240 \\
\hline & & SMCH4 & 1.2 & $\mid 0.1$ & & & 5.0 & 0.9 & & & & & & & & & 238 \\
\hline Cartagena & La Virgen & CLV1 & 0.8 & 0.0 & & & 5.2 & 0.0 & & & 2.4 & 0.9 & 11.5 & 1.1 & 44.4 & 8.4 & 148 \\
\hline & & CLV2 & 0.8 & 0.1 & & & 7.1 & 3.2 & & & 3.1 & 1.1 & \begin{tabular}{|l|}
12.1 \\
\end{tabular} & 1.1 & 38.1 & 10.6 & 219 \\
\hline & & CLV3 & 0.7 & 0.0 & & & 5.2 & 0.3 & & & 1.6 & 1.0 & 10.0 & 2.1 & 43.6 & 10.0 & 138 \\
\hline & Tierra Bomba & CTTB1 & 0.9 & 0.1 & & & 5.3 & 0.9 & & & 8.5 & 5.0 & 28.4 & 14.8 & 25.6 & 12.9 & 168 \\
\hline & & CTTB2 & 0.9 & 0.0 & & & 5.8 & 0.8 & & & 9.5 & 4.8 & 25.8 & 13.3 & 29.8 & 10.7 & 184 \\
\hline & & СТTВ3 & 1.0 & 0.0 & & & 4.8 & 1.2 & & & 6.6 & 5.2 & 21.1 & 16.6 & 28.6 & \begin{tabular}{|l|l|}
16.7 \\
\end{tabular} & 162 \\
\hline & Punta Arena & CTPA1 & 0.8 & 0.0 & & & 4.1 & 0.3 & & & 0.2 & 0.5 & \begin{tabular}{|l|}
6.8 \\
\end{tabular} & 3.8 & 47.6 & \begin{tabular}{|l|}
7.7 \\
\end{tabular} & 119 \\
\hline & & CTPA2 & 1.1 & 0.0 & & & 4.4 & 0.3 & & & 0.9 & 1.2 & 8.6 & 4.4 & 42.8 & 8.4 & 159 \\
\hline & & CTPA3 & 0.9 & 0.0 & & & 4.2 & 0.3 & & & 0.9 & 1.2 & 8.2 & 3.4 & 44.8 & 2.8 & 142 \\
\hline Continued & & & & & & & & & & & & & & & & & \\
\hline
\end{tabular}




\begin{tabular}{|c|c|c|c|c|c|c|c|c|c|c|c|c|c|c|c|c|c|}
\hline \multirow[b]{2}{*}{ Region } & \multirow[b]{2}{*}{ Location } & \multirow[b]{2}{*}{ Core ID } & \multicolumn{2}{|c|}{$\begin{array}{l}\text { DBD }(\mathrm{g} \\
\left.\mathrm{cm}^{-3}\right)\end{array}$} & \multicolumn{2}{|c|}{$\mathrm{C}_{\text {org }}(\%)$} & \multicolumn{2}{|c|}{ OM (\%) } & \multicolumn{2}{|c|}{$\delta^{13} \mathrm{C}(\%)$} & \multicolumn{2}{|c|}{$\begin{array}{l}<0.016 \mathrm{~mm} \\
(\%)\end{array}$} & \multicolumn{2}{|c|}{$\begin{array}{l}>0.016<0.125 \mathrm{~mm} \\
(\%)\end{array}$} & \multicolumn{2}{|c|}{$>0.5 \mathrm{~mm}$} & \multirow{2}{*}{ 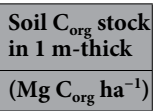 } \\
\hline & & & Mean & SD & Mean & SD & Mean & SD & Mean & SD & Mean & SD & Mean & SD & Mean & SD & \\
\hline & Cocon Bay & СТВC1 & 0.9 & 0.1 & & & 4.5 & 0.8 & & & 0.0 & 0.0 & 2.7 & 3.2 & 62.9 & 6.7 & 141 \\
\hline & & СТВС2 & 1.2 & 0.1 & & & 4.6 & 0.2 & & & 0.4 & 0.6 & 6.7 & 1.9 & 45.3 & 14.5 & 200 \\
\hline & & СТВС3 & 1.4 & 0.0 & & & 4.4 & 0.8 & & & 0.5 & 0.5 & 8.2 & 4.2 & 59.0 & 12.5 & 226 \\
\hline & Bocagrande & CTBG1 & 1.3 & 0.0 & & & 1.4 & 0.2 & & & 0.0 & 0.0 & 6.4 & 1.4 & 33.0 & 8.3 & 39 \\
\hline & & CTBG2 & 1.3 & 0.1 & & & 1.3 & 0.1 & & & 0.0 & 0.0 & 8.1 & 2.3 & 23.3 & \begin{tabular}{|l|}
10.8 \\
\end{tabular} & 40 \\
\hline & & СTBG3 & 1.9 & 0.5 & & & 1.0 & 0.2 & & & 0.0 & 0.0 & 5.1 & 2.9 & 31.0 & 6.5 & 40 \\
\hline OVERALL & & & 0.9 & 0.3 & 1.2 & 0.9 & 6.6 & 4.0 & -19.4 & 2.8 & 11.1 & 13.7 & 33.5 & 23.9 & 21.2 & 21.5 & $241 \pm 117$ \\
\hline
\end{tabular}

Table 1. Mean $( \pm \mathrm{SD})$ dry bulk density $\left(\mathrm{g} \mathrm{cm}^{-3}\right)$, organic carbon content $\left(\mathrm{C}_{\mathrm{org}}, \%\right)$, organic matter content (OM, \%), $\delta^{13} \mathrm{C}(\%)$, sediment grain-size $<0.016 \mathrm{~mm},>0.0 .016<0.125 \mathrm{~mm}$ and $>0.5 \mathrm{~mm}(\%)$ and soil organic carbon stocks (in $1 \mathrm{~m}$-thick, $\mathrm{kg} \mathrm{C}_{\text {org }} \mathrm{m}^{-2}$ ) in seagrass soils from all cores studied in the different locations and regions in the Colombian Caribbean.

\begin{tabular}{|c|c|c|c|c|c|c|}
\hline \multirow[b]{2}{*}{ Region } & \multirow[b]{2}{*}{ Location } & \multirow[b]{2}{*}{ Core ID } & \multirow{2}{*}{$\begin{array}{l}\text { Short-term SAR } \\
\left(\mathrm{mm}_{\text {year }}{ }^{-1}\right)\end{array}$} & \multirow{2}{*}{$\begin{array}{l}\text { Long-term SAR } \\
\left(\mathrm{mm} \mathrm{year}^{-1}\right)\end{array}$} & \multirow{2}{*}{$\begin{array}{l}\text { Short-term CAR } \\
\left(\mathrm{g} \mathrm{C}_{\text {org }} \mathrm{m}^{-2} \text { year }^{-1}\right)\end{array}$} & \multirow{2}{*}{$\begin{array}{l}\text { Long-term CAR } \\
\left(\mathrm{g} \mathrm{C}_{\text {org }} \mathrm{m}^{-2} \text { year }^{-1}\right)\end{array}$} \\
\hline & & & & & & \\
\hline \multirow[t]{2}{*}{ Alta Guajira } & Bahia Portete & AGBP2 & $1.8 \pm 0.3$ & & $93.3 \pm 17.1$ & \\
\hline & Bahia Hondita & AGBH3 & $0.89 \pm 0.16$ & $0.44 \pm 0.09$ & $33.6 \pm 5.9$ & $4.5 \pm 0.9$ \\
\hline \multirow[t]{2}{*}{ Media Guajira } & Carrizal & MGCZ3 & $3.3 \pm 0.8$ & & $79.5 \pm 20.1$ & \\
\hline & Musichi & MGMC1 & & $0.37 \pm 0.17$ & & $2.20 \pm 1.01$ \\
\hline \multirow[t]{3}{*}{ San Andrés } & Mar Azul & SAMA1 & $6.97 \pm 0.61$ & $3.36 \pm 1.35$ & $167 \pm 15$ & $27.5 \pm 11.1$ \\
\hline & Bahia Hooker & SABH1 & $5.97 \pm 0.28$ & $2.14 \pm 1.67$ & $164 \pm 8$ & $19.1 \pm 14.9$ \\
\hline & Cotton Cay & SACC1 & $4.55 \pm 0.15$ & $2.84 \pm 1.11$ & 195 & $21.2 \pm 8.2$ \\
\hline OVERALL & & & $3.9 \pm 0.4$ & $1.8 \pm 0.9$ & $122 \pm 62$ & $14.9 \pm 7.2$ \\
\hline
\end{tabular}

Table 2. Mean ( \pm SD) short-term (last decades) and long-term (last 2000 years) sediment accumulation rates (SAR; $\mathrm{mm}_{\text {year }}{ }^{-1}$ ) and organic carbon accumulation rates (CAR; $\mathrm{g} \mathrm{Corg}_{\mathrm{org}} \mathrm{m}^{-2} \mathrm{year}^{-1}$ ) in seagrass soils from all cores successfully dated in the different locations and regions in the Colombian Caribbean.

$\square$ Mangrove $\square$ Seagrass $\square$ Seston $:$ Halimeda tuna

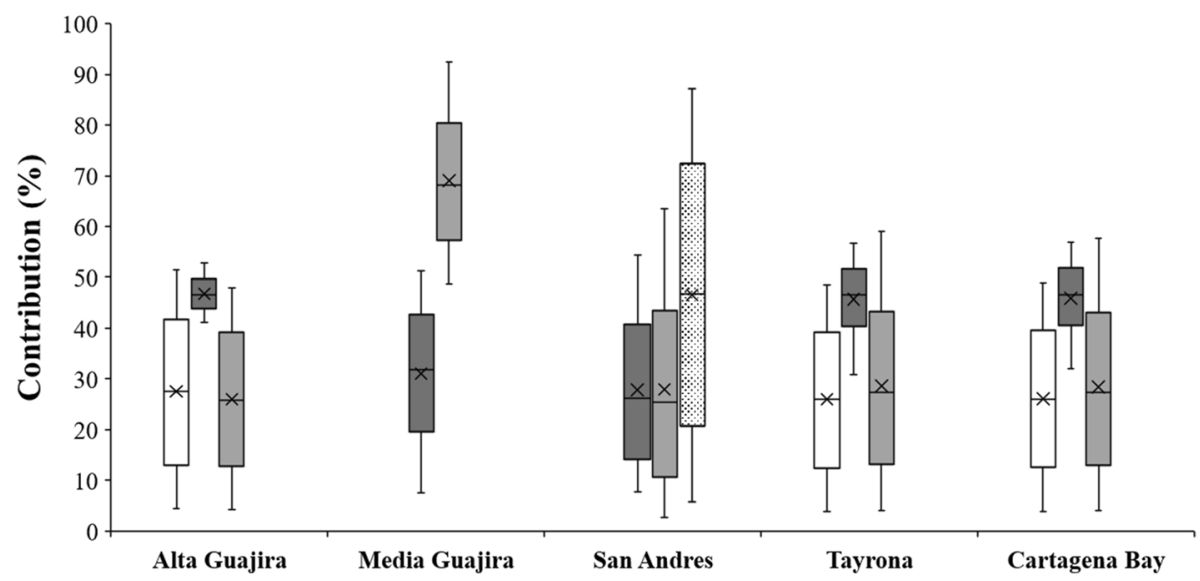

Figure 2. Box plots showing the results of the isotope mixing models to determine the contribution of sources (seagrass, seston, Halimeda tuna and mangrove) to the soil organic carbon pool in the five study sites.

\section{Discussion}

Seagrasses are sparsely distributed along the Colombian Caribbean, but their $\mathrm{C}_{\text {org }}$ stocks in $1 \mathrm{~m}$-thick soils (241 $\mathrm{Mg} \mathrm{C}_{\text {org }}$ ha $^{-1}$ on average) are well above the values from global estimates $\left(140 \mathrm{Mg} \mathrm{C}_{\text {org }} \text { ha }^{-1}\right)^{5}$ and other tropical regions such as Mexico, US and Indonesia (ranging ${ }^{23,33-35}$ from 71 to $170 \mathrm{Mg} \mathrm{C}_{\text {org }}$ ha $^{-1}$. Estimates of soil shortterm CAR ( $122 \mathrm{~g} \mathrm{C}_{\text {org }} \mathrm{m}^{-2}$ year $\left.^{-1}\right)$ in Colombian seagrass meadows is higher than in the Dutch Caribbean (84 $\mathrm{g}$ $\mathrm{C}_{\text {org }} \mathrm{m}^{-2}$ year $\left.{ }^{-1}\right)^{25}$ and Australian $\left(36 \mathrm{~g} \mathrm{C}_{\text {org }} \mathrm{m}^{-2} \text { year }^{-1}\right)^{21}$ meadows. The relatively high $\mathrm{C}_{\text {org }}$ sink capacity of Thalassia seagrass meadows in Colombia could be explained by a combination of biogeochemical and environmental 

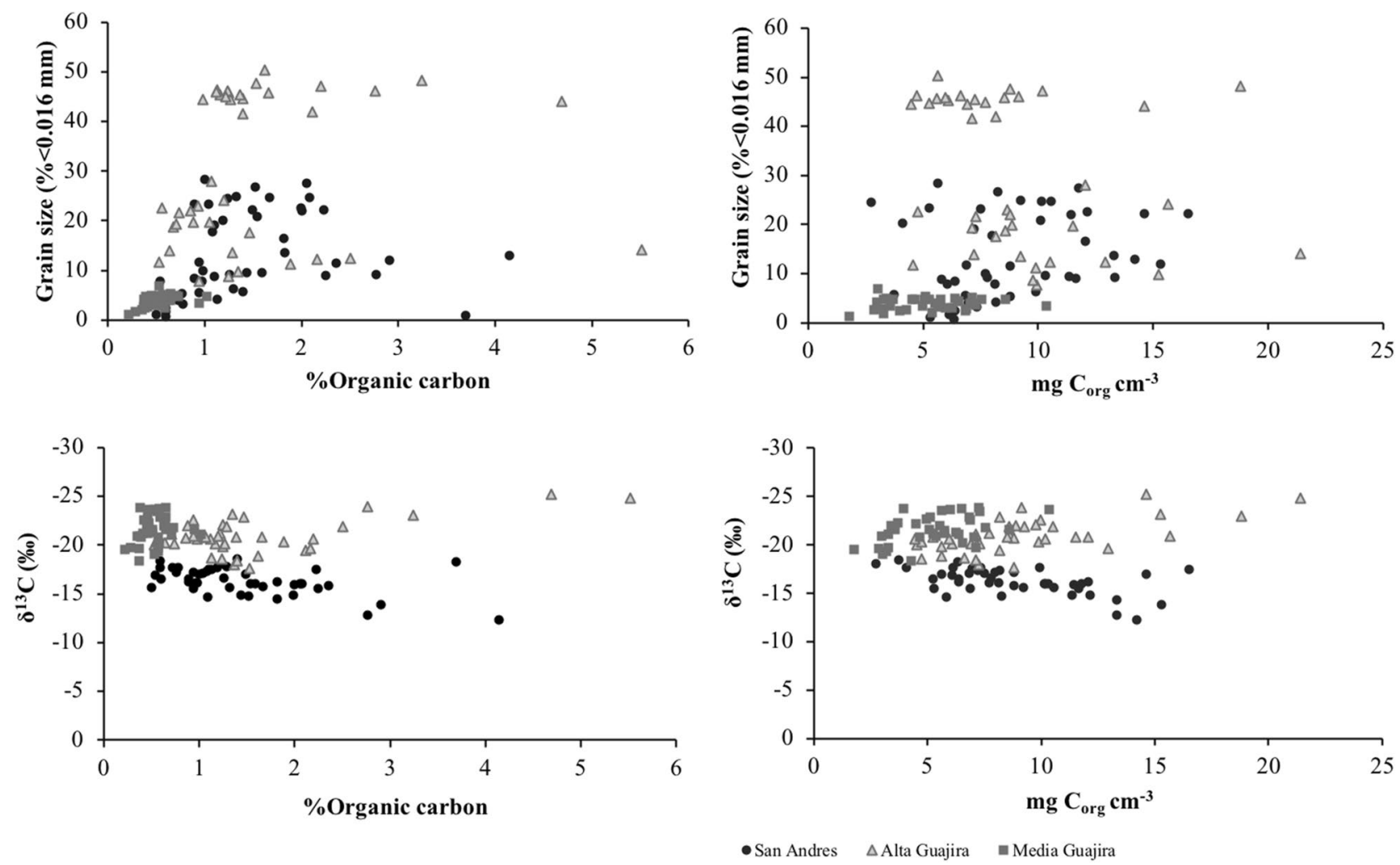

Figure 3. Relationships between soil organic carbon content $\left(\% \mathrm{C}_{\text {org }}\right.$ and $\left.\mathrm{mg} \mathrm{C}_{\text {org }} \mathrm{cm}^{-3}\right)$ and sediment particles $<0.016 \mathrm{~mm}$ and $\delta^{13} \mathrm{C}(\%)$ in the seagrass cores from San Andrés, Cartagena Bay and La Guajira in the Colombian Caribbean.

\begin{tabular}{|l|l|l|l|c|}
\hline Variable & Factor & F & df & P value \\
\hline Dry bulk density $\left(\mathrm{g} \mathrm{cm}^{-3}\right)$ & Region & 74.23 & 4 & $<0.001$ \\
\hline Organic carbon $(\%)$ & Region & 21.25 & 2 & $<0.001$ \\
\hline Organic matter $(\%)$ & Region & 83.73 & 4 & $<0.001$ \\
\hline $\mathrm{C}_{\text {org }}$ stocks $\left(\mathrm{Mg} \mathrm{C}_{\text {org }} \mathrm{ha}^{-1}\right)$ & Region & 12.47 & 4 & $<0.001$ \\
\hline$\delta^{13} \mathrm{C}(\%)$ & Region & 148.94 & 2 & $<0.001$ \\
\hline$<0.016 \mathrm{~mm}(\%)$ & Region & 93.36 & 3 & $<0.001$ \\
\hline$>0.016<0.125 \mathrm{~mm}(\%)$ & Region & 180.86 & 3 & $<0.001$ \\
\hline$>0.5 \mathrm{~mm}(\%)$ & Region & 145.13 & 3 & $<0.001$ \\
\hline
\end{tabular}

Table 3. Results of the Generalized Linear Models (GLM) testing for significant effects of region (Alta Guajira, Media Guajira, San Andrés, Tayrona, Cartagena) on seagrass soil dry bulk density $\left(\mathrm{g} \mathrm{cm}^{-3}\right)$, soil organic carbon content (\%), soil organic matter content $(\%)$, soil organic carbon stocks $\left(\mathrm{Mg} \mathrm{C}_{\mathrm{org}}\right.$ ha $^{-1}$ in $\left.1-\mathrm{m} \mathrm{thick}\right), \delta^{13} \mathrm{C}(\%)$, and content of sediment grain-sizes $<0.016 \mathrm{~mm},>0.0 .016<0.125 \mathrm{~mm}$ and $>0.5 \mathrm{~mm}$ (\%) in the Colombian Caribbean.

processes linked to habitat characteristics. The up to twofold higher above- and below-ground biomass and production of T. testudinum compared to the mean of seagrass species globally ${ }^{14}$, likely provides a relatively larger amount of seagrass detritus for burial. Indeed, the tropical wet climate in Colombia together with the numerous rivers discharging along the coastline results in the accumulation of fine-sized particles $<0.0125 \mathrm{~mm}(44 \pm 3 \%)$ within seagrass meadows (Fig. 4), which have been shown to be conductive of soil $\mathrm{C}_{\text {org }}$ preservation ${ }^{36,37}$. In turn, terrestrial run-off and mangrove vegetation deliver allochthonous $\mathrm{C}_{\text {org }}$ into the coastal zone that contributes to the seagrass soil carbon pool $(54 \pm 0.1 \%)^{38}$. SAR in Colombian seagrass meadows averaged $3.9 \pm 0.4 \mathrm{~mm}$ year $^{-1}$ over the last century, which are up to fourfold higher than previously reported for seagrass meadows globally ${ }^{1}$, and for China, Japan, Mediterranean Sea, Arabian Gulf and Australia (ranging from $0.8^{19,21,39}$ to $2.1 \mathrm{~mm}^{\text {year }}{ }^{-1}$, but similar to Zostera marina meadows ${ }^{20}$. High SAR entails rapid burial of organic matter in anoxic conditions thereby reducing $\mathrm{C}_{\text {org }}$ remineralization rates and enhancing $\mathrm{C}_{\text {org }}$ storage ${ }^{15}$. The lack of excess ${ }^{210} \mathrm{~Pb}$ in some of the cores analysed suggests that there is no net accumulation in some areas, or accumulation of reworked materials. Further studies (e.g. deployment of surface elevation tables to measure sediment accretion in situ) are required to overcome the limitations of radioisotopes ${ }^{40}$. Overall, the high seagrass primary production together with the 

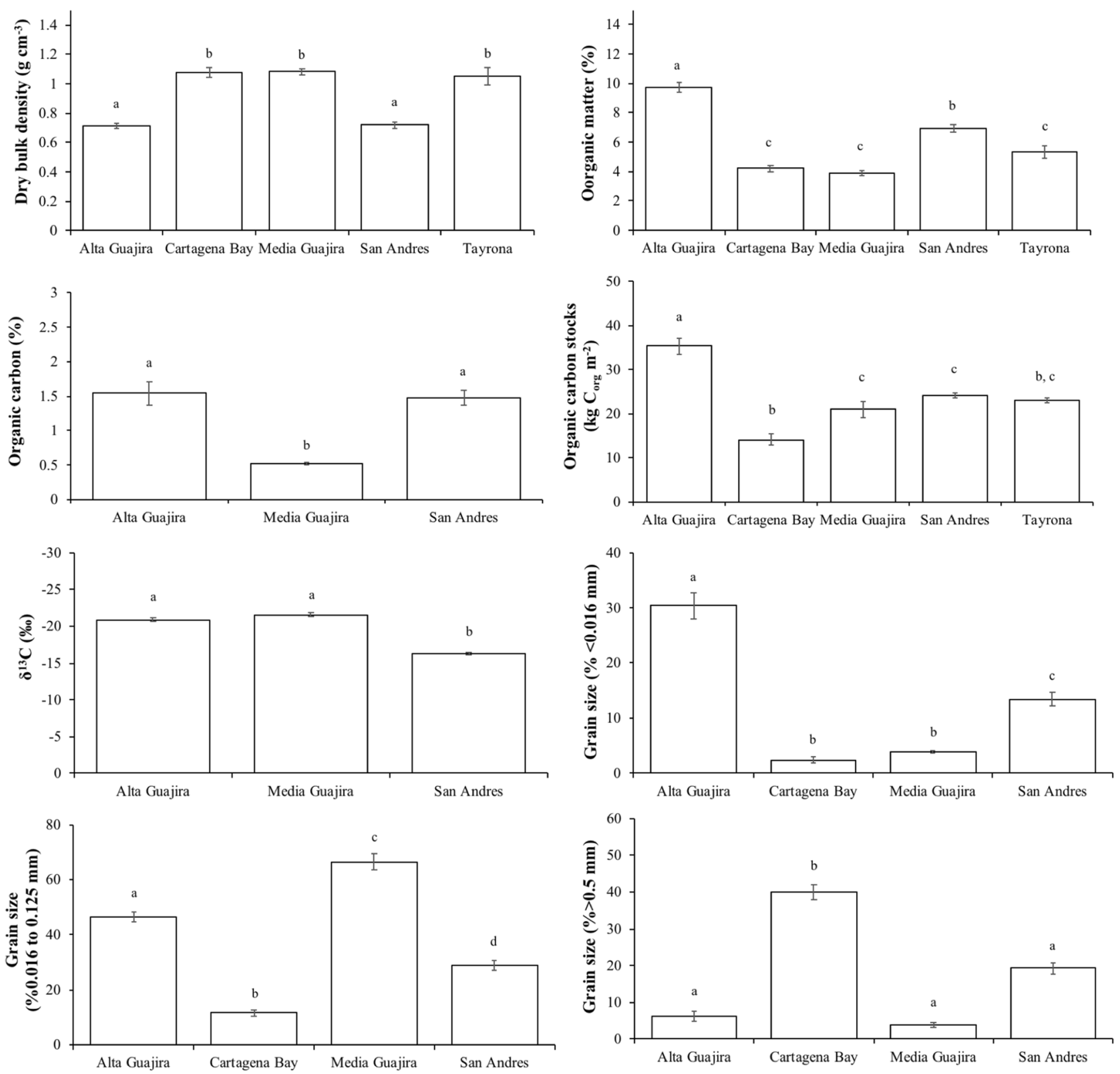

Figure 4. Mean $( \pm \mathrm{SE})$ dry bulk density $\left(\mathrm{g} \mathrm{cm}^{-3}\right)$, organic matter $(\%)$, organic carbon $\left(\% \mathrm{C}_{\text {org }}\right.$ and $\mathrm{kg} \mathrm{C}_{\text {org }} \mathrm{m}^{-2}$ in $1 \mathrm{~m}$-thick soils), $\delta^{13} \mathrm{C}(\%)$, and sediment grain-sizes $<0.016 \mathrm{~mm},>0.0 .016<0.125 \mathrm{~mm}$ and $>0.5 \mathrm{~mm}(\%)$ in seagrass soils from Alta Guajira, Cartagena Bay, Media Guajira and San Andrés in the Colombian Caribbean. Results of GLM tests to assess differences are denoted: different letters (a, b, c) indicate significant differences $(\mathrm{P}<0.05)$.

rapid accumulation of suspended particles results in highly depositional environments that enhance carbon accumulation and preservation, which could explain the relatively high $\mathrm{C}_{\text {org }}$ storage capacity of seagrass meadows along the Colombian Caribbean compared to other meadows globally.

Differences in seagrass soil carbon storage across Colombian regions. The up to threefold variability in seagrass soil $\mathrm{C}_{\text {org }}$ stocks among regions in the Colombian Caribbean appears to be largely linked to the relative contribution of $\mathrm{C}_{\text {org }}$ sources to the soil $\mathrm{C}_{\text {org }}$ pool (seagrass, algae, mangrove and seston) and inputs of fine sediment particles binding $\mathrm{C}_{\text {org }}$ and enhancing its preservation. The limited number of cores that were successfully dated with ${ }^{210} \mathrm{~Pb}$ and/or ${ }^{14} \mathrm{C}(\mathrm{N}=6$ each $)$ precluded comparison of CAR among regions.

La Guajira contains $88 \%$ of the country's T. testudinum seagrass extent $\left(581 \mathrm{~km}^{2}\right)$ and seagrass soil $\mathrm{C}_{\text {org }}$ stocks (12.4 Tg $\mathrm{C}_{\text {org }}$ ). Although Alta Guajira only contains $18 \mathrm{~km}^{2}$ of seagrass meadows, it holds the largest soil $\mathrm{C}_{\text {org }}$ stocks per unit area in Colombia $\left(352 \mathrm{Mg} \mathrm{C}_{\text {org }} \mathrm{ha}^{-1}\right)^{41}$, which also rank among the highest values reported globally ${ }^{5}$. The high soil $\mathrm{C}_{\text {org }}$ stocks per unit area in Alta Guajira are likely related to the high depositional nature of their habitats, restricted to enclosed embayments protected from hydrodynamic energy and hurricanes, with the exception of the meadows located in Cabo de la Vela ${ }^{42}$. The seagrass soil in Alta Guajira are mainly composed of 
soil inorganic particles $<0.125 \mathrm{~mm}(76 \%)$, which together with the contribution of mangrove and seston matter to the soil $\mathrm{C}_{\text {org }}$ pool ( $28 \%$ and $26 \%$, respectively) likely led to enhanced soil $\mathrm{C}_{\text {org }}$ accumulation and preservation in seagrass meadows (Figs. 2 and 4). The lack of correlation between particles $<0.016 \mathrm{~mm}$ and $\mathrm{C}_{\text {org }}$ content in Alta Guajira can be explained by the saturation of particles with adsorbed organic $\mathrm{C}_{\text {org }}$ together with the presence of coarse seagrass detritus ${ }^{37}$. The Alta Guajira region is exposed to extreme climate events driven by tropical storms and hurricanes, which can result in the sudden destruction of seagrass meadows ${ }^{41,42}$ and the erosion of seagrass soil $\mathrm{C}_{\text {org }}$ stocks ${ }^{43}$. Since the onset of seagrass monitoring at Cabo de la Vela in 2015, one cyclone disruption event resulted in the erosion of $>0.5$ ha of seagrass meadows and the top $\sim 0.6 \mathrm{~m}$ of soils underneath the meadows ${ }^{41}$, likely resulting in $\mathrm{CO}_{2}$ emissions from perturbed soil $\mathrm{C}_{\mathrm{org}}$ stocks. However, seagrasses in the protected embayments of Hondita Bay and Portete Bay within Alta Guajira remained undisturbed ${ }^{41}$. Further studies are required to assess the risk of tropical storms for blue carbon projects in tropical regions, in particular in the face of increased frequency and intensity of extreme climate events under predicted climate change scenarios ${ }^{44}$.

The relatively low seagrass soil $\mathrm{C}_{\text {org }}$ stocks in Media Guajira $\left(210 \mathrm{Mg} \mathrm{C}_{\text {org }}\right.$ ha $^{-1}$ ) compared to the Alta Guajira ( $352 \mathrm{Mg} \mathrm{C}_{\text {org }} \mathrm{ha}^{-1}$ ) is likely related to the severe exposure of meadows to hydrodynamic energy in the former. This region is constantly exposed to the currents and swell generated by strong winds from the East and Northeast, which results in the resuspension of particulate materials and turbid waters that limit the water depth limit for seagrass to up to $7 \mathrm{~m}$. These processes are reflected in the relatively low content of sediment particles $<0.016 \mathrm{~mm}$ $(4 \%)$ and dominance of particles $>0.016<0.125 \mathrm{~mm}(66 \%)$, which together with the low seagrass contribution to the soil $\mathrm{C}_{\text {org }}$ pool (31\%) compared to seston (69\%) suggests that meadows in this region are thriving in a highly dynamic environment compared to other Colombian Caribbean regions ${ }^{42}$ that could be limiting their productivity owing to reduced irradiance.

Meadows along the rocky coastline of Tayrona are restricted to enclosed environments protected from the swell (only $0.9 \mathrm{~km}^{2}$ of meadows mapped) ${ }^{31}$. The soil $\mathrm{C}_{\text {org }}$ stocks at our study site were relatively high $(231 \mathrm{Mg}$ $\mathrm{C}_{\text {org }} \mathrm{ha}^{-1}$ ), likely related to the high productivity of the meadows thriving in clear waters, and the input of seston and mangrove detritus from adjacent creeks. However, the lack of stable $\mathrm{C}_{\text {org }}$ isotope and grain size analyses in the cores from this region preclude further interpretations.

Seagrass meadows have been severely decimated at Cartagena Bay over the past decades (from $100 \mathrm{~km}^{2}$ in 1930s to $9 \mathrm{~km}^{2}$ in $2001^{45}$. In turn, only small patches of seagrass meadows $\left(<0.1 \mathrm{~km}^{2}\right.$ each) remain at Cartagena Bay, and their soil $\mathrm{C}_{\text {org }}$ stocks are the lowest found across Colombia $\left(142 \mathrm{Mg} \mathrm{C}_{\text {org }}\right.$ ha $\left.^{-1}\right)$. Previous studies showed that soil $\mathrm{C}_{\text {org }}$ stocks are lower in patchy seagrass landscapes compared to continuous and extensive meadows ${ }^{36,46}$. Indeed, coarse sand and gravel (40\%) originated from adjacent corals dominate the soil inorganic particles in Cartagena Bay' meadows, which together with the high degree of anthropization in the region could explain the weakening of seagrass $\mathrm{C}_{\text {org }}$ sinks in this region ${ }^{47}$.

Seagrass meadows in San Andrés and Providencia Archipelago $\left(5 \mathrm{~km}^{2}\right)$ are located in a coastal lagoon basin protected from currents and waves, and to a lesser degree from tropical storms and cyclones by a reef barrier, which facilitates sedimentation ${ }^{48,49}$ and likely explains the relatively high soil $\mathrm{C}_{\text {org }}$ stocks in this region $(241 \mathrm{Mg}$ $\left.\mathrm{C}_{\text {org }} \mathrm{ha}^{-1}\right)$. The short-term CAR reported for this region $\left(175 \mathrm{~g} \mathrm{C}_{\text {org }} \mathrm{m}^{-2} \mathrm{year}^{-1}\right)$ are the highest reported to date for seagrass meadows, with the exception of two P. oceanica meadows from the Mediterranean Sea (ranging from 202 to $249 \mathrm{~g} \mathrm{C}_{\mathrm{org}} \mathrm{m}^{-2}$ year $\left.^{-1}\right)^{50}$. The seagrass soils in San Andrés contain large amounts of $H$. tuna inorganic and organic (47\%) matter. The calcareous macroalgae Halimeda spp. is common in coral reefs and has very high primary production rates ${ }^{51,52}$ that likely contribute to enhance SAR through high carbonate production, and CAR through rapid burial of $\mathrm{C}_{\text {org }}$ in anoxic conditions. Further studies are required to understand the specific role of $H$. tuna in blue carbon, including the implications of calcification and dissolution in the carbon cycle ${ }^{53}$ as well as those enhancing CAR.

Seagrass blue carbon in the Colombian Caribbean. Seagrass T. testidinum in the Caribbean region of Colombia occupies $661 \mathrm{~km}^{2}$, with $18 \mathrm{~km}^{2}$ in Alta Guajira, $563 \mathrm{~km}^{2}$ in Media and Baja Guajira, $0.9 \mathrm{~km}^{2}$ in Tayrona, $9 \mathrm{~km}^{2}$ in Cartagena Bay, $5 \mathrm{~km}^{2}$ in San Andrés and surrounding islands, and $65 \mathrm{~km}^{2}$ in the Caribbean coastline west of Cartagena Bay ${ }^{45}$. Based on the spatially-explicit estimates of seagrass extent and soil $\mathrm{C}_{\text {org }}$ stocks and accumulation rates in the five regions studied (Fig. 4), we estimate that seagrass in the Colombian Caribbean contain $14 \mathrm{Tg}$ of $\mathrm{C}_{\text {org }}$ in the top meter of soils. This is equivalent to $52 \mathrm{Tg} \mathrm{CO}_{2}$ stored in the soils, which corresponds to $62 \%$ of the $\mathrm{CO}_{2}$ emissions from fossil-fuel burning by Colombia in $2014^{54}$. Based on average CAR estimates (122 $\mathrm{g} \mathrm{C}_{\text {org }} \mathrm{m}^{-2}$ year ${ }^{-1}$ over the last $\sim 70$ years), we estimated that seagrass meadows in the Colombian Caribbean accumulate $0.081 \mathrm{Tg} \mathrm{C}_{\text {org }}$ year $^{-1}$ (equivalent to $0.3 \mathrm{Tg} \mathrm{CO}_{2}$ year $^{-1}$ ), which corresponds to $\sim 0.4 \%$ of $\mathrm{CO}_{2}$ emissions from fossil fuels in Colombia at 2014 rates $^{54}$. It is important to note that these estimates are likely underestimating seagrass soil $\mathrm{C}_{\text {org }}$ storage in the Colombian Caribbean, owing to poor seagrass mapping in some regions and the exclusion of meadows formed by small species meadows of the genera Syringodium, Halophila, Halodule and Ruppia that occur in Colombia. However, owing to the lack of excess ${ }^{210} \mathrm{~Pb}$ in some meadows, further studies are required to determine whether some of the meadows studied continue to accumulate $\operatorname{soil~C}_{\text {org }}{ }^{40}$. Indeed, carbonate burial in seagrass meadows, which is particularly important in tropical regions, likely offsets a portion of the $\mathrm{CO}_{2}$ sequestered through the burial of $\mathrm{C}_{\text {org }}{ }^{53}$. Saderne et al ${ }^{55}$ estimated that $\mathrm{CaCO}_{3}$ burial within seagrass meadows may offset $\sim 30 \%$ of the net $\mathrm{CO}_{2}$ sequestration through photosynthesis, but acknowledged that the origin of $\mathrm{CaCO}_{3}$ stored within seagrass meadows is mostly derived from adjacent ecosystems rather than by calcifying organisms inhabiting or supported by seagrass ecosystems. In addition, the dissolution of $\mathrm{CaCO}_{3}$ linked to seagrass metabolism and associated biota, which is also common in tropical regions, results in the release of alkalinity and thereby $\mathrm{CO}_{2}$ removal $^{55,56}$. Further studies are required to decipher the role of inorganic carbon processing in the overall $\mathrm{CO}_{2}$ budget in seagrass meadows ${ }^{53,57}$. 
Our study demonstrates that Colombia host some of the largest seagrass soil carbon stocks per unit area globally (241 $\mathrm{Mg} \mathrm{C}_{\text {org }} \mathrm{ha}^{-1}$ in the top meter of soils), sitting between global median values (140 $\mathrm{Mg} \mathrm{C}_{\text {org }}$ ha $^{-1}$ ) and those of Posidonia oceanica meadows in the Mediterranean Sea $\left(375 \mathrm{Mg} \mathrm{C}_{\text {org }} \mathrm{ha}^{-1}\right)^{50}$. This characteristic in combination with the large losses of seagrass extent over the last decades in Caribbean Coast ${ }^{41,45}$, places Colombia among the countries that can largely benefit from blue carbon strategies to contribute to mitigate and adapt to climate change while preserving and restoring their natural heritage and enhancing the plethora of ecosystem services that vegetated coastal ecosystems provide ${ }^{2}$. Colombia hosts one of the few ongoing blue carbon projects in the world, involving carbon trading by protecting $270 \mathrm{~km}^{2}$ of mangrove forests from deforestation ${ }^{58}$.

In summary, this study demonstrates that seagrass meadows along the Colombian Caribbean are hotspots for carbon sequestration and storage, provides data from a new region to a growing dataset on seagrass blue carbon and further explores differences in soil $\mathrm{C}_{\text {org }}$ storage based on biotic and abiotic drivers. The spatially explicit estimates of seagrass soil $\mathrm{C}_{\text {org }}$ stocks contribute to identify key regions for conservation and management actions (including restoration) aiming to enhance $\mathrm{CO}_{2}$ sequestration and/or avoid greenhouse gas emissions resulting from seagrass loss, while providing the basis for the implementation of seagrass blue carbon strategies in Colombia. The reversal of historical seagrass losses can be traded in carbon markets and in this study, we provide baseline estimates of soil $\mathrm{C}_{\text {org }}$ stocks and accumulation rates in Colombian seagrasses to contribute to the conservation of seagrass ecosystems through seagrass restoration strategies at the national scale.

\section{Materials and methods}

Study sites and sampling. This study was conducted in five regions (Alta Guajira, Media Guajira, Tayrona, San Andrés, and Cartagena Bay) along $2250 \mathrm{~km}$ of the Colombian Caribbean (Fig. 1). Seagrass species T. testudinum forms the most extensive and apparent meadows along the Colombian coast. More than $85 \%$ of seagrass extent in Colombia is located within the Guajira peninsula (562 $\mathrm{km}^{2}$ out of the estimated $\left.661 \mathrm{~km}^{2}\right)^{45}$.

Seagrass meadows in Alta Guajira and Media Guajira grow not deeper than $7 \mathrm{~m}$ water depth on sandy habitats along the shoreline, and are exposed to regular wind-driven waves, with the exception of those meadows inhabiting the few existing embayment's. The meadows in La Guajira are not exposed to severe anthropogenic disturbances because the remoteness of the region, despite small indigenous and non-indigenous settlements may cause localized impacts ${ }^{31,45}$. Seagrass meadows in Tayrona National Natural Park grow in shallow sandy areas among corals and within embayment's, and the study sites are not impacted by direct anthropogenic activities. Cartagena Bay encompasses a wide variety of seagrass habitats with different gradients of anthropogenic disturbances (mainly from industry, boating activities and dredging) and geomorphological settings (open coastlines and embayment's) ${ }^{43}$. Seagrasses in San Andrés grow on shallow soil of weathered coral and the study sites are located near the main touristic village of the island ${ }^{59}$. Out of the studied regions, mangrove forests are only present in Alta Guajira, Tayrona and Cartagena Bay. La Guajira is characterized by a drier tropical climate (1100 annual precipitation) compared to the other studied regions located further west of the Colombian Caribbean (ranging from $1600 \mathrm{~mm}$ per year in Tayrona and Cartagena Bay to $1900 \mathrm{~mm}$ per year in San Andrés).

A total of 14 sites across the five regions were sampled in this study (Fig. 1). Sixty-one soil cores were sampled in 0.5 to $3 \mathrm{~m}$-deep meadows dominated by T. testudinum by manual percussion and rotation of PVC pipes (150 cm long, $65 \mathrm{~mm}$ inner diameter; Supplementary Information Table A). Three to twelve replicate cores were sampled within $200 \mathrm{~m}^{2}$ of each meadow at each site (61 cores in total). Soil compaction during coring was measured as the difference in surface soil elevation inside and outside the core ${ }^{60}$. The length of all cores was corrected for compaction (Supplementary Information Table A), and all results presented hereafter refer to the amended 'uncompressed' depths. The cores were sealed at both ends, and stored vertically at $4{ }^{\circ} \mathrm{C}$ until further processing. Seagrass plants (T. testudinum), mangrove (Rhizophora mangle) leaves, algae (H. tuna) and seston $(>0.7 \mu \mathrm{m})$ samples were collected across the study sites to determine of origin of soil $\mathrm{C}_{\text {org }}$ in seagrass meadows using stable carbon isotopes (Supplementary Information Table C).

Laboratory procedures. The cores were opened longitudinally using an electric saw and cut at 1 to $15 \mathrm{~cm}$ thick. The samples were dried at $60^{\circ} \mathrm{C}$ until constant weight to estimate the dry weight density $\left(\mathrm{g} \mathrm{cm}^{-3}\right)$, and then divided in two by quartering for subsequent analyses. One set of subsamples were milled using an electric mortar and used for soil organic matter and $\mathrm{C}_{\text {org }}$ content analyses to estimate soil $\mathrm{C}_{\text {org }}$ storage, and stable carbon isotope $\left(\delta^{13} \mathrm{C}\right)$ analysis to determine the sources of soil $\mathrm{C}_{\text {org. }}$. The other set of subsamples was used for radioisotope $\left({ }^{210} \mathrm{~Pb}\right.$ and ${ }^{14} \mathrm{C}$ ) dating of the cores and soil grain-size analysis to determine distribution of particle sizes. Organic matter analyses were run in all samples from all cores sampled $(\mathrm{N}=61)$, while $\mathrm{C}_{\text {org }}$ and grain-size analyses were only conducted in alternate samples along eight and 23 cores, respectively (Table 1).

For organic matter analyses, $4 \mathrm{~g}$ of milled sample was combusted at $550{ }^{\circ} \mathrm{C}$ for $4 \mathrm{~h}$ to estimate the proportionate loss of organic matter (loss on ignition, LOI $)^{61}$. For the analyses of soil $\mathrm{C}_{\text {org }}$ and $\delta^{13} \mathrm{C}, 2 \mathrm{~g}$ of ground sample was acidified with $4 \% \mathrm{HCl}$ to remove inorganic carbon, centrifuged (3400 revolutions per minute, for $5 \mathrm{~min}$ ), and the supernatant with acid residues was carefully removed by pipette, avoiding resuspension. The sample was then washed with Milli-Q water, centrifuged and the supernatant removed. The residual samples were re-dried and then encapsulated for $\mathrm{C}_{\text {org }}$ and $\delta^{13} \mathrm{C}$ analyses using a Thermo Delta V Conflo III coupled to a Costech 4010 at the UH Hilo Analytical Laboratory (USA). The $\mathrm{C}_{\text {org }}$ content was calculated for the bulk (pre-acidified) samples. Macrophyte samples containing inorganic carbon and seston were acidified prior to $\mathrm{C}_{\text {org }}$ analysis, following the procedures above for soils. Stable carbon isotope ratios $\left(\delta^{13} \mathrm{C}\right)$ are expressed as $\delta$ values in parts per thousand (\%o) relative to the Vienna PeeDee Belemnite standard. Replicate assays and standards indicated measurement errors of $0.02 \%$ for $\mathrm{C}_{\text {org }}$ content and $0.07 \%$ for $\delta^{13} \mathrm{C}$. Sediment grain size was measured with a Coulter LS230 laserdiffraction particle analyzer at the University of Barcelona (Spain), after digestion of organic matter with $30 \%$ $\mathrm{H}_{2} \mathrm{O}_{2}$. The grain size data was classified in the following fractions: $<0.016 \mathrm{~mm},>0.016<0.125 \mathrm{~mm}$ and $>0.5 \mathrm{~mm}$. 
Concentrations of ${ }^{210} \mathrm{~Pb}$ were determined by alpha spectrometry through the measurement of its granddaughter ${ }^{210} \mathrm{Po}$, assuming radioactive equilibrium between the two radionuclides ${ }^{62}$. Between 150 and $300 \mathrm{mg}$ of each sample were spiked with known amounts of ${ }^{209} \mathrm{Po}$ and acid digested using a microwave oven. The Po isotopes were plated onto silver discs (99.99\% purity) and their emissions were measured by alpha spectrometry using Passivated Implanted Planar Silicon (PIPS) detectors (CANBERRA, Mod. PD-450.18 A.M.) and silicon surface barrier detectors (ORTEC, mod. Ensemble). A selection of samples from some cores was measured for ${ }^{226} \mathrm{Ra}$ by gamma spectrometry using a high-purity Ge well-type detector (CANBERRA, Mod. GCW3523) to determine the concentrations of supported ${ }^{210} \mathrm{~Pb}$, used to calculate the excess ${ }^{210} \mathrm{~Pb}$ concentrations were calculated. The ${ }^{226} \mathrm{Ra}$ concentrations were found to be comparable to those of ${ }^{210} \mathrm{~Pb}$ at depth in those cores, and thus the later were taken as supported ${ }^{210} \mathrm{~Pb}$ for the rest of the cores. The average sediment accumulation rates over the past 100 years could be estimated for six of the eleven dated sediment cores using the Constant Flux:Constant Sedimentation (CF:CS) model below the mixed surface layer when present ${ }^{63}$. The other cores showed either evidence of intense mixing or negligible presence of excess ${ }^{210} \mathrm{~Pb}$ that precluded estimating a sedimentation rate.

A total of 17 radiocarbon analyses were conducted in the bulk soil organic matter in seven cores sampled across the five regions $\left(1-3{ }^{14} \mathrm{C}\right.$ analyses per core; Supplementary Information Table B) at the AMS Direct Laboratory (USA) following standard procedures ${ }^{64}$. The ${ }^{14} \mathrm{C}$ age-depth models were produced using the $\mathrm{R}$ routine "Bacon" for Bayesian chronology building ${ }^{65}$, after calibration of ${ }^{14} \mathrm{C}$ ages using the marine 13 radiocarbon age calibration curve, considering a local delta $\mathrm{R}$ of $25 \pm 8$ years ${ }^{66}$, and assuming that the top core corresponded to the year of sampling. In two cores, the ${ }^{14} \mathrm{C}$ results showed that either the core was mixed or that the samples were younger than $\sim 400$ years and therefore, it was not possible to estimate age-depth chronologies based on ${ }^{14} \mathrm{C}$ in these cores. All ${ }^{14} \mathrm{C}$ ages reported in this study are expressed as radiocarbon calibrated years.

Numerical procedures. A linear regression between $\% \mathrm{C}_{\text {org }}$ and $\% \mathrm{LOI}\left(\mathrm{R}^{2}=0.78\right)$ was used to estimate the $\% \mathrm{C}_{\text {org }}$ content for subsamples that were not analyzed for $\mathrm{C}_{\text {org }} 5$. The density of organic carbon $\left(\mathrm{g} \mathrm{C}_{\text {org }} \mathrm{cm}^{-3}\right)$ was calculated for each core slice by multiplying the sediment dry bulk density $\left(\mathrm{g} \mathrm{cm}^{-3}\right)$ by the $\mathrm{C}_{\text {org }}$ concentration (\%). To allow direct comparisons among locations, the soil $\mathrm{C}_{\text {org }}$ stocks per unit area (cumulative stocks; $\mathrm{Mg} \mathrm{C}_{\text {org }}$ $\mathrm{ha}^{-1}$ ) were standardized to $1 \mathrm{~m}$-thick deposits. When sediment cores (32 out of 61$)$ were shorter than $100 \mathrm{~cm}(65$ to $90 \mathrm{~cm}$ ), soil $\mathrm{C}_{\text {org }}$ stocks in the top $1 \mathrm{~m}$ were estimated by extrapolating the integrated values of $\mathrm{C}_{\text {org }}$ content (cumulative $\mathrm{C}_{\text {org }}$ stock; $\mathrm{Mg} \mathrm{C}_{\text {org }}$ ha $^{-1}$ ) linearly with depth. To validate this extrapolation approach, we assessed the correlation between extrapolated $\mathrm{C}_{\text {org }}$ stocks from $65 \mathrm{~cm}$ to $1 \mathrm{~m}$ and measured $\mathrm{C}_{\text {org }}$ stocks in $1 \mathrm{~m}$ soil cores across the 29 sampled cores that were equal or longer than $100 \mathrm{~cm}(\mathrm{r}=0.97 ; \mathrm{P}<0.001$; Supporting Information Figure B). Soil $\mathrm{C}_{\text {org }}$ accumulation rates (expressed in $\mathrm{g} \mathrm{C}_{\text {org }} \mathrm{m}^{-2}$ year ${ }^{-1}$ ) for the last century and the last 2500 years were estimated using ${ }^{210} \mathrm{~Pb}$ and ${ }^{14} \mathrm{C}$ age-depth models, respectively. Short-term (based on ${ }^{210} \mathrm{~Pb}$ ) and long-term (based on ${ }^{14} \mathrm{C}$ ) soil $\mathrm{C}_{\text {org }}$ accumulation were calculated in 6 and 5 out of the 61 cores sampled, respectively, by multiplying the $\mathrm{C}_{\text {org }}$ inventories in $1 \mathrm{~m}$-thick soil by the respective average soil accretion rate $\left(\mathrm{cm} \mathrm{year}^{-1}\right)$.

Pearson correlation analyses were run to assess significant relationships between soil $\mathrm{C}_{\text {org }}$ storage (stocks in $\mathrm{Mg} \mathrm{C}_{\text {org }}$ ha $^{-1}$ and short- and long-term accumulation rates in $\mathrm{g}_{\text {org }} \mathrm{m}^{-2}$ year ${ }^{-1}$ ) and soil $\delta^{13} \mathrm{C}$ and particles $<0.016 \mathrm{~mm}$. Statistical analyses were performed using univariate General Linear Models (GLM) procedures in Statgraphics v16 software. The GLMs were run to test for significant effects of region (Alta Guajira, Media Guajira, San Andrés, Tayrona and Cartagena) on the soil organic carbon content $\left(\% \mathrm{C}_{\text {org }}\right)$, soil $\mathrm{C}_{\text {org }}$ stocks $(\mathrm{Mg}$ $\left.\mathrm{C}_{\text {org }} \mathrm{ha}^{-1}\right)$, short- and long-term soil $\mathrm{C}_{\text {org }}$ accumulation rates $\left(\mathrm{g} \mathrm{C}_{\text {org }} \mathrm{m}^{-2}\right.$ year $\left.{ }^{-1}\right)$, stable carbon isotope values of soil $\mathrm{C}_{\text {org }}\left(\delta^{13} \mathrm{C}\right), \%<0.016 \mathrm{~mm}, \% 0.016$ to $0.125 \mathrm{~mm}$ and $\%>0.5 \mathrm{~mm}$ (Table 3 ). Region was treated as fixed factor and all response variables were square-root transformed prior to analyses to meet homogeneity of variance. Normality and homoscedasticity of model residuals were assessed visually.

One-isotope, two- to three-source mixing models were run in $\mathrm{R}$ using simmr and rjags packages ${ }^{67,68}$. The isotope used in this model was $\delta^{13} \mathrm{C}$, and the types and values of source end-members used varied across regions based on the presence/absence of potential sources and the specific values obtained for each region. Seagrass, mangrove and seston were included for Alta Guajira, Tayrona and Cartagena Bay, while only seagrass and seston were included for the Media Guajira region, and seagrass, seston and H. tuna for San Andrés (Supplementary Information Table C). The reference isotopic signatures (mean \pm SD) used in this model comprised $\delta^{13} \mathrm{C}$ values from this study.

Received: 27 November 2020; Accepted: 6 May 2021

Published online: 26 May 2021

\section{References}

1. Duarte, C. M., Losada, I. J., Hendriks, I. E., Mazarrasa, I. \& Marbà, N. The role of coastal plant communities for climate change mitigation and adaptation. Nat. Clim. Change 3, 961-968 (2013).

2. Cullen-Unsworth, L. C. et al. Seagrass meadows globally as a coupled social-ecological system: Implications for human wellbeing. Mar. Pollut. Bull. 83, 387-397 (2014).

3. Nellemann, C. et al. Blue Carbon: a rapid response assessment. United Nations Environment Programme, GRID-Arendal (2009).

4. Mcleod, E. et al. A blueprint for blue carbon: toward an improved understanding of the role of vegetated coastal habitats in sequestering CO2. Front. Ecol. Environ. 9, 552-560 (2011).

5. Fourqurean, J. W. et al. Seagrass ecosystems as a globally significant carbon stock. Nat. Geosci. 5, 505-509 (2012).

6. Waycott, M. et al. Accelerating loss of seagrasses across the globe threatens coastal ecosystems. PNAS 106, 12377-12381 (2009).

7. de los Santos, C. B. et al. Recent trend reversal for declining European seagrass meadows. Nature Commun. 10, 1-8 (2019).

8. Lefcheck, J. S. et al. Long-term nutrient reductions lead to the unprecedented recovery of a temperate coastal region. PNAS 115, 3658-3662 (2018). 
9. Pendleton, L. et al. Estimating global "blue carbon" emissions from conversion and degradation of vegetated coastal ecosystems. PLoS ONE 7, e43542 (2012).

10. Macreadie, P. I. et al. The future of Blue Carbon science. Nat. Commun. 10, 1-13 (2019).

11. Jayathilake, D. R. M. \& Costello, M. J. A modelled global distribution of the seagrass biome. Biol. Conserv. 226, 120-126 (2018).

12. McKenzie, L. et al. The global distribution of seagrass meadows. Environ. Res. Lett. 15, 074041 (2020).

13. Den Hartog, C., \& Kuo, J. Taxonomy and biogeography of seagrasses. In Seagrasses: biology, ecology and conservation (pp. 1-23). Springer, Dordrecht (2007).

14. Duarte, C. M. \& Chiscano, C. L. Seagrass biomass and production: a reassessment. Aquat. Bot. 65, 159-174 (1999).

15. Serrano, O., Lavery, P. S., Rozaimi, M. \& Mateo, M. A. Influence of water depth on the carbon sequestration capacity of seagrasses. Global Biogeochemic. Cy. 28, 950-961 (2014).

16. Gullström, M. et al. Blue carbon storage in tropical seagrass meadows relates to carbonate stock dynamics, plant-sediment processes, and landscape context: insights from the western Indian Ocean. Ecosystems 21, 551-566 (2018).

17. Lavery, P. S., Mateo, M. Á., Serrano, O. \& Rozaimi, M. Variability in the carbon storage of seagrass habitats and its implications for global estimates of blue carbon ecosystem service. PLoS ONE 8, e73748 (2013).

18. Campbell, J. E., Lacey, E. A., Decker, R. A., Crooks, S. \& Fourqurean, J. W. Carbon storage in seagrass beds of Abu Dhabi United Arab Emirates. Estuaries Coast 38, 242-251 (2015).

19. Miyajima, T. et al. Geographic variability in organic carbon stock and accumulation rate in sediments of East and Southeast Asian seagrass meadows. Global Biogeochemic. Cy. 29, 397-415 (2015).

20. Röhr, M. E. et al. Blue carbon storage capacity of temperate eelgrass (Zostera marina) meadows. Global Biogeochemic. Cy. 32, $1457-1475$ (2018).

21. Serrano, O. et al. Australian vegetated coastal ecosystems as global hotspots for climate change mitigation. Nat. Commun. 10, 1-10 (2019).

22. Prentice, C. et al. A synthesis of blue carbon stocks, sources and accumulation rates in eelgrass (Zostera marina) meadows in the Northeast Pacific. Global Biogeochemic. Cy. 34, e2019GB006345 (2020).

23. Herrera-Silveira, J. A. et al. Blue carbon of Mexico, carbon stocks and fluxes: a systematic review. PeerJ 8, e8790 (2020).

24. Carruthers, T. J. B., Barnes, P. A., Jacome, G. \& Fourqurean, J. W. Lagoon scale processes in a coastally influenced Caribbean system: implications for the seagrass Thalassia testudinum. Caribb. J. Sci. 41, 441-455 (2005).

25. Tamis, J. E., \& Foekema, E. M. A review of blue carbon in the Netherlands. IMARES Report C151/15. 13 p. (2016).

26. Thorhaug, A. L. et al. Gulf of Mexico estuarine blue carbon stock, extent and flux: Mangroves, marshes, and seagrasses: A North American hotspot. Sci. Total Environ. 653, 1253-1261 (2019).

27. Novak, A. B. et al. Factors influencing carbon stocks and accumulation rates in eelgrass meadows across New England, USA. Estuaries Coast. 43, 2076-2091 (2020).

28. Howard, J. L., Creed, J. C., Aguia, M. V. \& Fourqurean, J. W. CO2 released by carbonate sediment production in some coastal areas may offset the benefits of seagrass "Blue Carbon". Limnol. Oceanogr. 63, 160-172 (2018).

29. Nóbrega, G. N., Romero, D. J., Otero, X. L., \& Ferreira, T. O. Pedological studies of subaqueous soils as a contribution to the protection of seagrass meadows in Brazil. Rev Bras Cienc Solo 42 (2018).

30. Gómez-Lopez, D., C. et al. Informe técnico Final Proyecto de Actualización cartográfica del atlas de pastos marinos de Colombia: Sectores Guajira, Punta San Bernardo y Chocó: Extensión y estado actual. PRY-BEM-005-13 FONADE-INVEMAR. Santa Marta. 136 pp. (2014).

31. Díaz, M., Barrios Suárez, L. M., \& Gómez López, D. I. Las praderas de pastos marinos en Colombia: Estructura y distribución de un ecosistema estratégico, Instituto de Investigaciones Marinas y Costeras-INVEMAR (2003).

32. Green, E. P., Short, F. T., \& Frederick, T. World atlas of seagrasses. Univ of California Press (2003).

33. Phang, V. X., Chou, L. M. \& Friess, D. A. Ecosystem carbon stocks across a tropical intertidal habitat mosaic of mangrove forest, seagrass meadow, mudflat and sandbar. Earth Surf Process Landf 40, 1387-1400 (2015).

34. Alongi, D. M. et al. Indonesia's blue carbon: a globally significant and vulnerable sink for seagrass and mangrove carbon. Wetl. Ecol. Manag. 24, 3-13 (2016).

35. Thorhaug, A., Poulos, H. M., López-Portillo, J., Ku, T. C. \& Berlyn, G. P. Seagrass blue carbon dynamics in the Gulf of Mexico: Stocks, losses from anthropogenic disturbance, and gains through seagrass restoration. Sci. Total Environ. 605, 626-636 (2017).

36. Oreska, M. P., McGlathery, K. J. \& Porter, J. H. Seagrass blue carbon spatial patterns at the meadow-scale. PLoS ONE 12, e0176630 (2017).

37. Serrano, O. et al. Can mud (silt and clay) concentration be used to predict soil organic carbon content within seagrass ecosystems?. Biogeosciences 17, 4915-4926 (2016).

38. Chen, G. et al. Mangroves as a major source of soil carbon storage in adjacent seagrass meadows. Sci. Rep. 7, 42406 (2017).

39. Cusack, M. et al. Organic carbon sequestration and storage in vegetated coastal habitats along the western coast of the Arabian Gulf. Environ. Res. Lett. 13, 074007 (2018).

40. Lafratta, A. et al. Challenges to select suitable habitats and demonstrate 'additionality' in Blue Carbon projects: A seagrass case study. Ocean Coast. Manag. 197, 105295 (2020).

41. Gómez-López, D.I. et al. Reporte del estado de los arrecifes coralinos y pastos marinos en Colombia (2016-2017). Serie de publicaciones Generales del Invemar \# 101, Santa Marta. 100 pp. (2018).

42. Alvarez-León, R., Aguilera-Quiñonez, J., Andrade-Maya, C. C. \& Novak, P. Caracterización general de la zona de surgencia en la Guajira Colombiana. Rev. Acad. Colomb. Cienc. 19, 679-694 (1995).

43. Wilson, S. S., Furman, B. T., Hall, M. O. \& Fourqurean, J. W. Assessment of Hurricane Irma impacts on South Florida seagrass communities using long-term monitoring programs. Estuaries Coast. 43, 1119-1132 (2020).

44. Hiraishi, T. et al. 2013 supplement to the 2006 IPCC guidelines for national greenhouse gas inventories: Wetlands. IPCC, Switzerland (2014).

45. Diaz-M, J. M. \& Gómez-López, D. I. Historic changes in the abundance and distribution of seagrass beds in the Cartagena bay and neighbouring areas (Colombia). Bol. Invest. Mar. Cost. 32, 57-74 (2003).

46. Ricart, A. M. et al. High variability of Blue Carbon storage in seagrass meadows at the estuary scale. Sci. Rep. 10, 1-12 (2020).

47. Macreadie, P. I., Allen, K., Kelaher, B. P., Ralph, P. J. \& Skilbeck, C. G. Paleoreconstruction of estuarine sediments reveal humaninduced weakening of coastal carbon sinks. Glob. Change Biol. 18, 891-901 (2012).

48. Geister, J., \& Díaz-Merlano J. M. Reef environments and geology of an oceanic archipelago: San Andrés, Old Providence and Santa Catalina (Caribbean Sea, colombia) with Field Guide. Ingeominas. 104 pp (2007).

49. Rodríguez-Ramírez, A. et al. Recent dynamics and condition of coral reefs in the Colombian Caribbean. Rev. Biol. Trop. 58, 107-131 (2010).

50. Serrano, O., Lavery, P. S., Lopez-Merino, L., Ballesteros, E. \& Mateo, M. A. Location and associated carbon storage of erosional escarpments of seagrass Posidonia mats. Front. Mar. Sci. 3, 42 (2016).

51. Freile, D., \& Hillis, L. Carbonate productivity by Halimeda incrassata land in a proximal lagoon, Pico Feo, San Blas, Panama. In Proceedings 8th International Coral Reef Symposium 1, 767-772 (1997).

52. van Tussenbroek, B. I. \& van Dijk, J. K. Spatial and temporal variability in biomass and production of Psammophytic Halimeda incrassata (Bryopsidales, Chlorophyta) in a Caribbean reef lagoon. J. Phycol. 43, 69-77 (2007). 
53. Macreadie, P. I., Serrano, O., Maher, D. T., Duarte, C. M. \& Beardall, J. Addressing calcium carbonate cycling in blue carbon accounting. Limnol. Oceanogr. Lett. 2, 195-201 (2017).

54. CDIAC, 2020. Carbon Dioxide Information Analysis Center

55. Saderne, V. et al. Role of carbonate burial in Blue Carbon budgets. Nat. Commun. 10, 1-9 (2019).

56. Challener, R. C., Robbins, L. L. \& McClintock, J. B. Variability of the carbonate chemistry in a shallow, seagrass-dominated ecosystem: implications for ocean acidification experiments. Mar. Freshw. Res. 67, 163-172 (2016).

57. Gattuso, J. P. et al. Ocean solutions to address climate change and its effects on marine ecosystems. Front. Mar. Sci. 5, 337 (2018).

58. Conservation International (2020). Accesses in November 2020. https://www.conservation.org/stories/critical-inves tment-in-blue-carbon

59. Coralina-Invemar. Gómez-López, D. I., C. Segura-Quintero, P. C. Sierra-Correa y J. Garay-Tinoco (Eds). Atlas de la Reserva de Biósfera Seaflower. Archipiélago de San Andrés, Providencia y Santa Catalina. Instituto de Investigaciones Marinas y Costeras "José Benito Vives De Andréis" -INVEMAR- y Corporación para el Desarrollo Sostenible del Archipiélago de San Andrés, Providencia y Santa Catalina -CORALINA-. Serie de Publicaciones Especiales de INVEMAR \# 28. Santa Marta, Colombia 180 p. (2012).

60. Glew, J. R., Smol, J. P., \& Last, W. M. Sediment Core Collection and Extrusion. In: Tracking Environmental Change UsingLake Sediments. Kluwer Academic Publishers, 73-105 (2005).

61. Heiri, O., Lotter, A. F. \& Lemcke, G. Loss on ignition as a method for estimating organic and carbonate content in sediments: reproducibility and comparability of results. J. Paleolimnol. 25, 101-110 (2001).

62. Sanchez-Cabeza, J. A., Masqué, P. \& Ani-Ragolta, I. 210Pb and 210Po analysis in sediments and soils by microwave acid digestion. J. Radioanal. Nucl. Chem. 227, 19-22 (1998).

63. Krishnaswamy, S., Lal, D., Martin, J. M. \& Meybeck, M. Geochronology of lake sediments. Earth Planet. Sci. Lett. 11, 407-414 (1971).

64. Stuiver, M. \& Polach, H. A. Discussion reporting of 14 C data. Radiocarbon 19, 355-363 (1977).

65. Blaauw, M. \& Christen, J. A. Flexible paleoclimate age-depth models using an autoregressive gamma process. Bayesian Anal. 6, 457-474 (2011).

66. Reimer, P. J. et al. IntCal13 and Marine13 radiocarbon age calibration curves 0-50,000 years cal BP. Radiocarbon 55, 1869-1887 (2013).

67. Parnell, A. C. et al. Bayesian stable isotope mixing models. Environmetrics 24, 387-399 (2013).

68. Parnell, A. C. Package “simmr": A Stable Isotope Mixing Model. https://doi.org/10.1371/journal.pone.0009672 (2019).

\section{Acknowledgements}

The research reported in this paper was supported by MAPCO Action Grant contract for European Union external actions ENV/2016/380-526 cofounded by INVEMAR and Fundación Natura (Colombia,) with the support of ECU (Australia) and CSIC (project COOPB20366, I-COOP+ program, Spain). Its contents are the sole responsibility of the authors and do not necessarily reflect the views of the European Union. O.S. was supported by an ARC DECRA (DE170101524). C.S. was supported by ECU Higher Degree by Research Scholarship. P.M. was supported by the Australian Research Council LIEF Project (LE170100219). The IAEA is grateful for the support provided to its Environment Laboratories by the Government of the Principality of Monaco. This is the Contribution \#1306 from INVEMAR. This study complies with national and international guidelines, legislation and permits for the collection of plant and soil specimens. The macrophytes used in this study were identified by D.I.G.-L. and O.S. and have been deposited in the public museum collection at INVEMAR (Santa Marta, Colombia).

\section{Author contributions}

O.S drafted the first version of this manuscript. All authors collated and analyzed data and contributed to the writing of this manuscript.

\section{Competing interests}

The authors declare no competing interests.

\section{Additional information}

Supplementary Information The online version contains supplementary material available at https://doi.org/ 10.1038/s41598-021-90544-5.

Correspondence and requests for materials should be addressed to O.S.

Reprints and permissions information is available at www.nature.com/reprints.

Publisher's note Springer Nature remains neutral with regard to jurisdictional claims in published maps and institutional affiliations.

Open Access This article is licensed under a Creative Commons Attribution 4.0 International License, which permits use, sharing, adaptation, distribution and reproduction in any medium or format, as long as you give appropriate credit to the original author(s) and the source, provide a link to the Creative Commons licence, and indicate if changes were made. The images or other third party material in this article are included in the article's Creative Commons licence, unless indicated otherwise in a credit line to the material. If material is not included in the article's Creative Commons licence and your intended use is not permitted by statutory regulation or exceeds the permitted use, you will need to obtain permission directly from the copyright holder. To view a copy of this licence, visit http://creativecommons.org/licenses/by/4.0/.

(C) The Author(s) 2021 